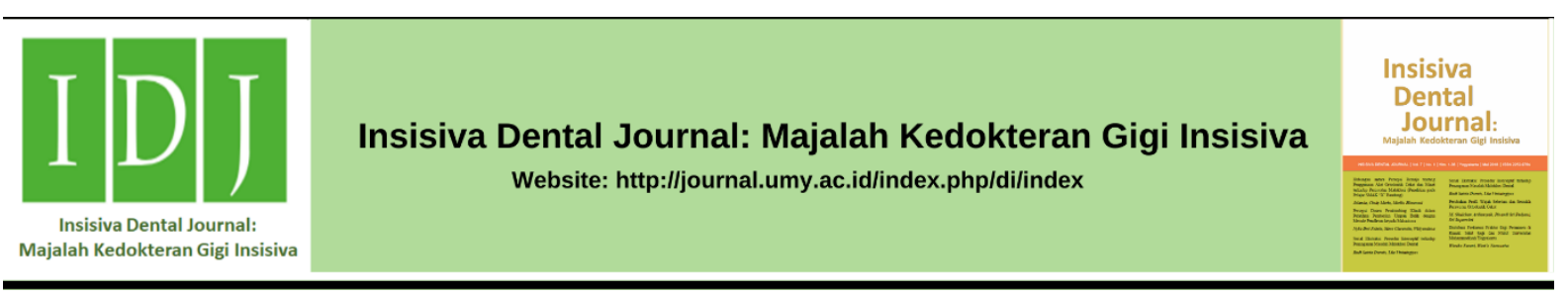

Research Article

\title{
Perbandingan Keakuratan Penentuan Usia Antara Metode Demirjian, Cameriere, dan Blenkin-Taylor
}

Comparison of Age Estimation Accuracy Between Demirjian, Cameriere, And Blenkin-Taylor Methods

\author{
Erwin Setyawan*, Dimas Setiyanto, Latifa Wahyudi Putri \\ Departemen Radiologi, Program Studi Kedokteran Gigi, Fakultas Kedokteran dan Ilmu Kesehatan, Universitas Muhammadiyah Yogyakarta, \\ Jalan Brawijaya, Tamantirto, Kasihan, Bantul, Daerah Istimewa Yogyakarta 55183, Indonesia.
}

Received date: October $23^{\text {rd }}, 2021$; revised date: November $11^{\text {st }}, 2021$; accepted: November $25^{\text {th }}, 2021$

DOI: 10.18196/di.v10i1.12972

\begin{abstract}
Abstrak
Banyaknya korban meninggal yang disebabkan oleh bencana massal atau kejadian lainnya perlu dilakukan proses identifikasi untuk mengetahui identitas para korban. Proses identifikasi salah satunya dapat dilakukan menggunakan teknik dental records dalam menentukan identitas individu. Metode penentuan usia menggunakan dental records yang paling sering digunakan adalah metode Demirjian, serta terdapat metode baru dalam penentuan usia yaitu metode Cameriere dan metode Blenkin-Taylor. Penelitian ini bertujuan untuk membandingkan keakuratan penentuan usia antara metode Demirjian, Cameriere, dan Blenkin-Taylor pada pasien di RSGM UMY. Metode pada penelitian ini adalah observasional analitik dengan jumlah sampel adalah 95 foto radiograf dari pasien berusia 4-15 tahun yang berkunjung ke Rumah Sakit Gigi dan Mulut Universitas Muhammadiyah Yogyakarta (RSGM UMY) pada bulan januari hingga desember 2017. Analisis data pada penelitian ini menggunakan uji statistik Chi-Square Test dan crosstabulation menggunakan software spss. Hasil menunjukkan bahwa metode Demirjian memiliki keakuratan sebesar 66.31\% (63 sampel), metode Cameriere memiliki keakuratan sebesar 51.57\% (49 sampel) dan metode Blenkin-Taylor sebesar 54.74\% (52 sampel). Analisis statistik ketiga metode tersebut tidak memiliki perbedaan yang bermakna dalam keakuratan penentuan usia pasien. Kesimpulan dalam penelitian ini adalah metode Demirjian, Cameriere, dan Blenkin-Taylor tidak memiliki perbedaan keakuratan dalam penentuan usia.
\end{abstract}

Kata Kunci: Blenkin-Taylor; Cameriere; Demirjian; Panoramic; Usia

\begin{abstract}
The number of victims caused by mass disasters or other events needs to be identified to find out the identity of the victims. One of the identification processes can be carried out using dental records in determining individual identity. The method of determining the age of using dental records, which is most commonly used, is the Demirjian method. However, there are new methods in determining the age, namely the Cameriere method and the Blenkin-Taylor method. This study aims to compare the accuracy between the Demirjian, Cameriere, and Blenkin-Taylor methods in patients at RSGM UMY. This study utilized an observational analytical method, with 95 radiographs taken from patients aged 4-15 years who visited RSGM UMY from January to December 2017. Data analysis used the Chi-Square Statistical Test and crosstabulation on spss. The result showed that the Demirjian method had an accuracy of 63 samples (66.31\%), the Cameriere method had an accuracy of 49 samples (51.57\%), and the Blenkin-Taylor method amounted to 52 samples (54.74\%). The three methods had no difference in statistical analysis in the age estimation of patients. Furthermore, Demirjian, Cameriere, and Blenkin-Taylor's methods did not have different accuracy in age estimation.
\end{abstract}

Keywords: Age; Blenkin-Taylor; Cameriere; Demirjian; Panoramic

\footnotetext{
*Corresponding author, e-mail: erwinsetyawan@fkik.umy.ac.id
} 


\section{PENDAHULUAN}

Banyaknya korban meninggal yang disebabkan oleh bencana massal atau kejadian lainnya perlu dilakukan proses identifikasi untuk mengetahui identitas para korban. Metode yang dapat digunakan untuk melakukan identifikasi adalah metode identifikasi forensik. ${ }^{1}$ Disaster Victim Identification (DVI) membagi metode tersebut menjadi 5 fase dalam proses identifikasi yang memiliki keterkaitan antara satu dengan yang lain. Primary Identifier meliputi fingerprint (FP), dental records (DR) dan DNA sedangkan Secondary Identifiers terdiri dari medical $(\mathrm{M})$, property $(\mathrm{P})$ dan photography (PG). $\stackrel{2}{ }$

Teknik dental records telah dikenal lama sejak era sebelum masehi dan dikenal dengan istilah forensik odontologi. Penggunaan gigi dalam teknik ini sangat berguna dalam kedokteran gigi forensik karena gigi merupakan bagian terkeras dari tubuh manusia. $\frac{3}{\text { Jaringan pada gigi dilapisi }}$ oleh materi anorganik kristal hidroksiapatit sehingga mempunyai daya tahan yang tinggi terhadap suhu serta beragam jenis pengaruh eksternal, iritasi mekanik, dan

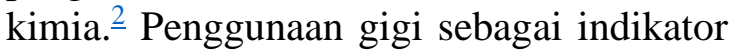
untuk menilai dan menentukan umur seseorang dapat dilihat dari aspek morfologis, histologis dan radiografis..$^{4}$ Hasil radiografis mampu memberikan informasi tentang tahapan mineralisasi gigi, tingkat pembentukan mahkota, dan erupsi mahkota di dalam rongga mulut. $\underline{5}$

Salah satu metode yang menggunakan foto radiograf panoramik untuk menentukan diagram perkembangan gigi dalam perhitungannya adalah metode Demirjian. Metode ini menggunakan dasar pada tahapan perkembangan tujuh gigi permanen rahang kiri bawah, dilihat kriteria bentuk, nilai relatif, serta bukan pada panjang mutlak gigi.

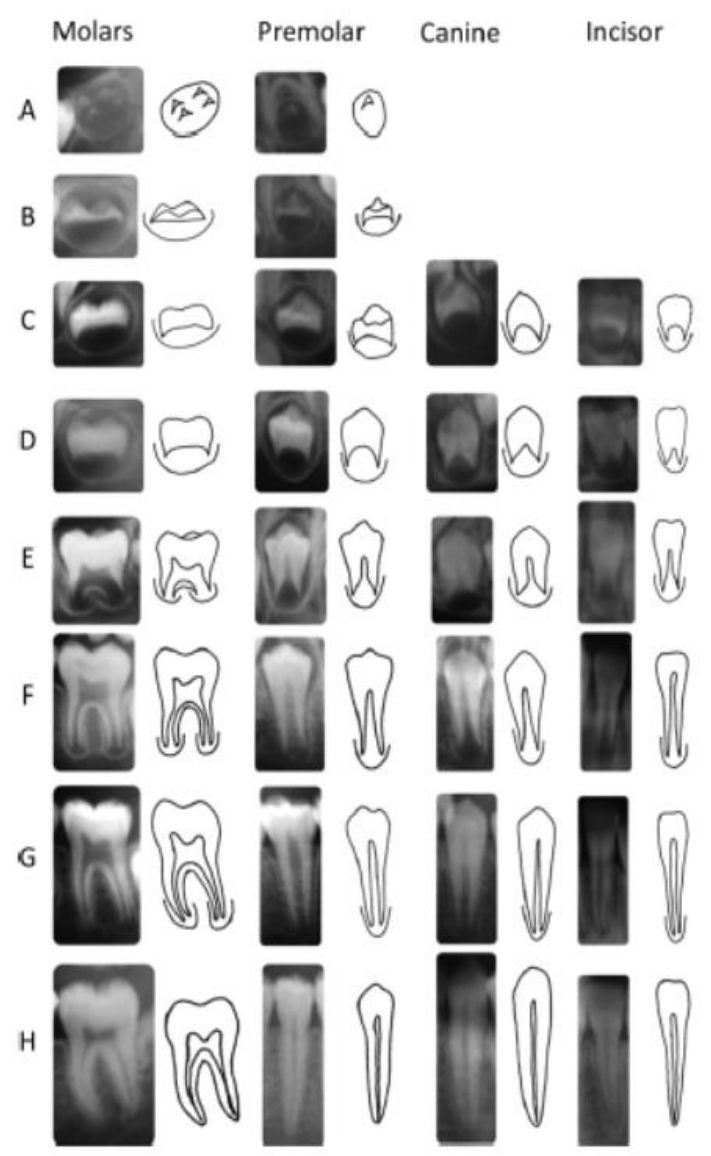

Gambar 1. Tahap kalsifikasi gigi permanen menurut Demirjian dkk., $\underline{6}$

Estimasi usia kronologis memiliki delapan tahapan yang mencakup kalsifikasi mahkota dan akar hingga penutupan apeks pada masing-masing gigi seperti pada gambar 1. $\frac{6}{}$ Metode penentuan usia kronologis berdasarkan pada pengukuran apeks terbuka pertama kali diperkenalkan oleh Roberto Cameriere pada tahun 2006 (gambar 2). Metode ini melihat perkembangan di tujuh gigi permanen rahang bawah sebelah kiri. Roberto Cameriere melakukan banyak penelitian di berbagai negara di Eropa dan Amerika termasuk Meksiko pada 2012 dan dari hasil penelitian tersebut menunjukkan keakuratan yang lebih baik dari metode yang lain. ${ }^{7}$ 


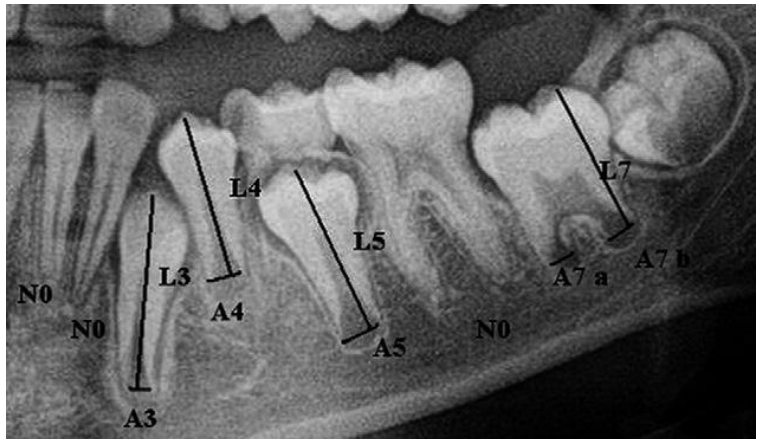

Gambar 2. Perhitungan apeks terbuka menurut Cameriere, dkk., $\stackrel{?}{ }$

Metode baru yang dipublikasikan dengan sistem diagram dan dianggap lebih mudah serta lebih cepat diaplikasikan adalah metode Blenkin-Taylor pada tahun 2012.. Berdasarkan hasil analisis data dalam membandingkan beberapa metode dengan menggunakan atlas ataupun diagram, didapatkan akurasi dari metode atlas tergolong rendah secara keseluruhan, namun metode atlas Blenkin-Taylor secara signifikan mengungguli yang lain untuk persentase kesesuaiannya dengan usia kronologis. ${ }^{9}$

Beberapa metode penentuan usia ini memiliki kelebihan masing-masing dalam proses penentuan usia, untuk itu perlu diketahui akurasi dari penentuan usia dengan metode Demirjian, Cameriere, dan Blenkin-Taylor pada pasien di RSGM UMY.

\section{MATERIAL DAN METODE}

Penelitian ini merupakan penelitian observasional analitik dengan desain penelitian cross sectional. Penelitian ini menggunakan rancangan penelitian analitik untuk mengetahui perbedaan keakuratan dari tiga metode penentuan usia. Sampel berjumlah 95 foto panoramik yang berasal dari pasien yang periksa di RSGM UMY dengan berbagai keluhan dan pernah difoto panoramik (Belmont X-Caliber CM Panoramic) di instalasi radiologi. Penelitian ini sudah mendapatkan ethical clearance yang dikeluarkan oleh Komite Etik Penelitian Fakultas Kedokteran Dan Ilmu Kesehatan Universitas Muhammadiyah
Yogyakarta nomor 610/EP-FKIKUMY/XII/2018.

Foto panoramik diidentifikasi perkiraan usia berdasarkan pertumbuhan gigi yang terlihat pada radiograf. Hasil identifikasi perkiraan usia dikatakan akurat jika dibandingkan dengan usia kronologis memiliki perkiraan usia kisaran 1 tahun diatas maupun satu tahun dibawah dari usia kronologis.

\section{HASIL}

Sampel foto panoramik harus memuat data penunjang yang digunakan meliputi nama pasien, tanggal lahir, tanggal pengambilan foto radiograf serta nomor rekam medis pasien. Distribusi subjek penelitian dapat dilihat pada tabel 1 .

Tabel 1. Distribusi subjek

tahun Laki-laki Perempuan Total

\begin{tabular}{ccccccc} 
& $\mathrm{n}$ & $\%$ & $\mathrm{n}$ & $\%$ & $\mathrm{~N}$ & $\%$ \\
& & & & & & \\
\hline $4-5.9$ & 7 & 7.3 & 2 & 2.1 & 9 & 9.47 \\
\hline $6-7.9$ & 7 & 7.3 & 10 & 10.52 & 17 & 17.89 \\
\hline $8-9.9$ & 16 & 16.84 & 17 & 17.89 & 33 & 34.73 \\
& & & & & & \\
\hline $10-11.9$ & 10 & 10.52 & 11 & 11.62 & 21 & 22.14 \\
\hline $12-13.9$ & 5 & 5.25 & 5 & 5.25 & 10 & 10.52 \\
\hline $14-15.9$ & 3 & 3.15 & 2 & 2.1 & 5 & 5.25 \\
\hline Total & 48 & 50.52 & 47 & 49.48 & 95 & 100 \\
\hline
\end{tabular}

Berdasarkan tabel 1, menunjukkan bahwa kelompok umur termuda pada umur 4-5,9 tahun dan yang tertua umur 14-15,9 tahun. Sampel terbanyak pada kelompok umur 8-9,9 tahun.

Radiograf panoramik yang ada kemudian diidentifikasi untuk ditentukan perkiraan usia menggunakan metode Demirjian, Cameriere dan Blenkin-Taylor. Hasil perkiraan usia berdasarkan gambar radiografis dapat dilihat pada tabel 2 . 
Tabel 2. Perkiraan usia gigi antara metode Demirjian, Cameriere, dan metode Blenkin-Taylor berdasarkan gambar radiografis.

\begin{tabular}{cccccccc}
\hline & \multicolumn{9}{c}{ Akurasi } \\
\hline \multirow{2}{*}{ Metode } & \multicolumn{2}{c}{ Akurat } & \multicolumn{2}{c}{$\begin{array}{c}\text { Tidak } \\
\text { akurat }\end{array}$} & \multicolumn{2}{c}{ Total } \\
\cline { 2 - 8 } & $\mathrm{n}$ & $\%$ & $\mathrm{n}$ & $\%$ & $\mathrm{~N}$ & $\%$ \\
\hline Demirjian & 63 & 66.31 & 32 & 33.69 & 95 & 100 \\
\hline Cameriere & 49 & 51.57 & 46 & 48.43 & 95 & 100 \\
\hline $\begin{array}{c}\text { Blenkin- } \\
\text { Taylor }\end{array}$ & 52 & 54.74 & 43 & 45.26 & 95 & 100 \\
\hline
\end{tabular}

Berdasarkan tabel 2 terlihat bahwa persentase keakuratan yang tertinggi pada metode Demirjian yaitu sebesar $66,31 \%$. Ketidakakuratan dari ketiga metode perkiraan penentuan usia antara $33,69 \%$ $48,43 \%$.

Perkiraan penentuan usia berdasarkan jenis kelamin dapat dilihat pada tabel 3 dan tabel 4.

Tabel 3. Perkiraan usia gigi antara Demirjian, Cameriere, dan metode Blenkin-Taylor berdasarkan gambar radiografis menurut jenis kelamin laki-laki

\begin{tabular}{ccccccc}
\hline \multicolumn{1}{c}{ Akurasi } \\
\hline \multirow{2}{*}{ Metode } & \multicolumn{1}{c}{ Akurat } & \multicolumn{2}{c}{ Tidak akurat } & \multicolumn{2}{c}{ Total } \\
\cline { 2 - 8 } & $\mathrm{n}$ & $\%$ & $\mathrm{n}$ & $\%$ & $\mathrm{~N}$ & $\%$ \\
\hline Demirjian & 31 & 65.95 & 16 & 34.05 & 47 & 100 \\
\hline Cameriere & 21 & 44.68 & 26 & 55.32 & 47 & 100 \\
\hline $\begin{array}{c}\text { Blenkin- } \\
\text { Taylor }\end{array}$ & 27 & 57.45 & 20 & 42.55 & 47 & 100 \\
\hline
\end{tabular}

Tabel 4. Perkiraan usia gigi antara metode Demirjian, Cameriere, dan metode Blenkin-Taylor berdasarkan gambar radiografis menurut jenis kelamin perempuan

\begin{tabular}{ccccccc}
\hline & \multicolumn{9}{c}{ Akurasi } \\
\hline \multirow{2}{*}{ Metode } & \multicolumn{2}{c}{ Akurat } & \multicolumn{2}{c}{$\begin{array}{c}\text { Tidak } \\
\text { akurat }\end{array}$} & \multicolumn{2}{c}{ Total } \\
\cline { 2 - 7 } & $\mathrm{n}$ & $\%$ & $\mathrm{n}$ & $\%$ & $\mathrm{~N}$ & $\%$ \\
\hline Demirjian & 32 & 66.67 & 16 & 33.33 & 48 & 100 \\
\hline Cameriere & 28 & 58.34 & 20 & 41.66 & 48 & 100 \\
\hline $\begin{array}{c}\text { Blenkin- } \\
\text { Taylor }\end{array}$ & 25 & 52.08 & 23 & 47.92 & 48 & 100 \\
\hline
\end{tabular}

Berdasarkan tabel 3 dan 4 terlihat bahwa persentase keakuratan menurut jenis kelamin laki-laki dan perempuan yang tertinggi pada metode Demirjian dan ketidakakuratan terbesar pada jenis kelamin laki-laki pada metode Cameriere dan pada jenis kelamin perempuan pada metode Blenkin-Taylor.

Tabel 5. Hasil uji statistik dengan paired sample test

\begin{tabular}{llccc}
\hline & $\mathrm{t}$ & $\mathrm{df}$ & $\begin{array}{r}\text { Sig. (2- } \\
\text { tailed) }\end{array}$ \\
\hline Pair 1 & $\begin{array}{l}\text { demirjian - } \\
\text { cameriere }\end{array}$ & 1.924 & 94 & .057 \\
\hline Pair 2 & $\begin{array}{l}\text { blenkin_taylor } \\
\text { - demirjian }\end{array}$ & -1.636 & 94 & .105 \\
\hline Pair 3 & $\begin{array}{l}\text { cameriere - } \\
\text { blenkin_taylor }\end{array}$ & -.293 & 94 & .770
\end{tabular}

Rata-rata akurasi ketiga metode dilakukan uji statistik dengan paired sample T-test untuk melihat tingkat signifikansi perbedaan rata-rata tersebut seperti terlihat pada tabel 5. Sig. (2-tailed) terlihat dalam tiap pair menunjukkan angka dengan nilai $\mathrm{p}>0.05$.

\section{PEMBAHASAN}

Perkiraan penentuan usia seseorang dapat dilakukan berdasarkan pada maturasi gigi menggunakan tahap waktu erupsi dan kalsifikasi gigi. Metode yang menggunakan tahap waktu erupsi gigi memiliki kekurangan antara lain sulit menentukan waktu erupsi yang sebenarnya karena kejadiannya berlangsung cepat, penilaiannya secara klinis dan dipengaruhi faktor lokal, penyakit sistemik serta pola makan. Penentuan usia gigi menggunakan tahap kalsifikasi gigi memiliki tahap yang lebih konsisten dalam menentukan tahap maturasi gigi. $\frac{10}{}$

Berdasarkan tabel 2 terlihat bahwa akurasi pada metode Demirjian menunjukkan tingkat yang tinggi. Tingginya tingkat keakuratan tersebut karena metode Demirjian merupakan penilaian kualitatif tentang bentuk dan ukuran gigi. Metode ini telah digunakan sejak 1973 dan terus digunakan karena pengaplikasian yang mudah. Metode ini memberikan penjelasan lebih detail tentang 
definisi setiap tahap perkembangan gigi menggunakan atlas dan memberikan contoh gambaran radiografisnya sehingga dapat lebih spesifik dalam penentuan usia untuk megurangi masalah interpretasi secara subjektif terhadap gambaran foto radiograf. .11

Hasil analisis data secara statistik pada tabel 5 terlihat bahwa nilai $\mathrm{p}>0.05$, hal ini menunjukkan tidak adanya perbedaan yang signifikan. Hasil penelitian ini berbeda dari hipotesis yaitu tidak ada perbedaan yang bermakna keakuratan penentuan usia dari ketiga metode. Perbedaan dengan hipotesis tersebut dapat disebabkan karena variasi individu yang berbeda, ras dan budaya, perbedaan genetik serta faktor tempat dan lingkungan yang mempengaruhi. $\stackrel{12}{~}$ Foto radiograf panoramik menjadi salah satu faktor penting dalam proses perkiraan penentuan usia tersebut. Proses perhitungan dalam menentukan perkiraan usia menggunakan foto radiograf juga membutuhkan keterampilan dan ketepatan dalam pengukuran. Mutu radiografi termasuk kejelasan dan ketepatan dimensi gambar juga mempengaruhi interpretasi dan ketepatan pengukuran. Kualitas foto radiograf mengacu pada ketepatan gambaran struktur dan visibilitas detail tiap gambaran struktur anatomi tersebut. $\underline{13}$ Hasil foto radiograf dapat ditingkatkan dengan penggunaan dentai $x$-ray teknologi terkini yaitu computed radiography dan digital radiography karena memiliki kelebihan dalam hasil gambar dan tidak melewati proses pencetakan film sehingga dapat meminimalkan distorsi dari hasil foto radiograf.

Genetik, status sosial ekonomi, kondisi gizi, kebiasaan diet dan kondisi iklim tempat tinggal merupakan beberapa penyebab dalam variasi kematangan gigi diantara populasi dan kelompok etnis yang berbeda. $\stackrel{14}{~ P e r b e d a a n}$ ras dapat menyebabkan perbedaan waktu dan urutan erupsi gigi permanen. Lokasi penelitian juga mempengaruhi hasil dari perhitungan perkiraan usia yang di lakukan. Motede cameriere memiliki tingkat keakuratan yang tinggi pada sampel yang dilakukan di eropa, sehingga rumus pada metode Cameriere dapat mempresentasikan penduduk Eropa. $\stackrel{15}{ }$ Perbedaan ras antara penduduk Eropa dan Asia tersebut mempengaruhi hasil dari perhitungan akar gigi terbuka menggunakan metode Cameriere yang dilakukan oleh peneliti di RSGM UMY.

Penentuan usia menggunakan gigi memiliki keunggulan serta kekurangan pada masing-masing metode, sehingga diperlukan pengujian secara berulang untuk meningkatkan keakuratan dalam perhitungan perkiraan usia. Jumlah sampel, metode statistik yang digunakan serta ketepatan peneliti dalam menggunakan metode sangat berpengaruh terhadap hasil penentuan usia gigi. $\frac{11}{}$

Penelitian ini juga mengelompokkan sampel berdasarkan jenis kelamin dalam menentukan perkiraan usia seperti pada tabel 3 dan tabel 4. Hasil dari analisis perhitungan perkiraan usia menggunakan ketiga metode menunjukkan hasil bahwa pada jenis kelamin perempuan memiliki tingkat keakuratan yang lebih tinggi dibandingkan dengan jenis kelamin lakilaki. Hasil tersebut dapat terjadi karena perempuan mempunyai periode pertumbuhan prepubertas dan pubertas sehingga perempuan memiliki usia dental yang menyamai atau lebih cepat dibandingkan dengan laki-laki. ${ }^{16}$ Beberapa peneliti menyatakan bahwa terdapat kesesuaian usia yang lebih baik pada sampel dengan jenis kelamin perempuan dibandingkan sampel dengan jenis kelamin laki-laki. $\underline{17}$

\section{KESIMPULAN}

Tidak terdapat perbedaan keakuratan dalam penentuan usia antara metode Demirjian, Cameriere, dan Blenkin-Taylor terhadap usia kronologis. Perkiraan usia gigi secara keseluruhan pada pada perempuan lebih akurat dibanding pada pasien laki-laki. 


\section{DAFTAR PUSTAKA}

1. Corradi LM, Travassos DV, Coste SC, Moura RNV de, Ferreira EF e. Identifying missing people: the contribution of forensic dentistry and DNA. Rev Odontol UNESP. 2017;13; 46(6):313-8.

https://dx.doi.org/10.1590/1807$\underline{2577.02817}$

2. Garg Y, Bhaskar DJ. Forensic Dentistry: An Aid in Criminal Investigation. ForensicDent.2015;1(6):4.

3. Tandaju CF, Siwu J, Hutagalung BSP. Gambaran pemeriksaan gigi untuk identifikasi korban meninggal di Bagian Kedokteran Forensik dan Medikolegal RSUP Prof. Dr. R. D. Kandou Manado tahun 2010 - 2015. EGiGi.2017;5(1):96-99. https://doi.org/10.35790/eg.5.1.2017.1 $\underline{5534}$

4. Chandramala R, Sharma R, Khan M, Srivastava A. Application of Kvaal's Technique of Age Estimation on Digital Panoramic Radiographs. Dentistry; 2012;2:142.

5. Halilah T, Khdairi N, Jost-Brinkmann P-G, Bartzela T. Age estimation in 516-year-old children by measurement of open apices: North German formula. Forensic Sci Int. 2018;293:103. https://doi.org/10.1016/j.forsciint.2018 .09 .022

6. Demirjian A, Goldstein H, Tanner JM. A New System of Dental Age Assessment. Hum Biol. 1973;45(2): 211-227.

7. Cameriere R, Pacifici A, Pacifici L, Polimeni A, Federici F, Cingolani M, et al. Age estimation in children by measurement of open apices in teeth with Bayesian calibration approach. Forensic Sci Int. 2016;258:50-54. https://doi.org/10.1016/j.forsciint.2015 .11 .005
8. Blenkin M, Taylor J. Age estimation charts for a modern Australian population. Forensic Sci Int. 2012; 221(1):106-112.

https://doi.org/10.1016/j.forsciint.2012 .04 .013

9. Baylis S, Bassed R. Precision and accuracy of commonly used dental age estimation charts for the New Zealand population. Forensic Sci Int. 2017;277 :223-228.

https://doi.org/10.1016/j.forsciint.2017 .06 .011

10. Ajmal M, Assiri KI, Al-Ameer KY, Assiri AM, Luqman M. Age estimation using third molar teeth: A study on southern Saudi population. J Forensic Dent Sci. 2012;4(2):63-65. https://doi.org/10.4103/0975$\underline{1475.109886}$

11. Apriyono DK. Metode Penentuan Usia Melalui Gigi dalam Proses Identifikasi Korban. Cermin Dunia Kedokt. 2016;43(1):71-74.

12. Rai B, Kaur J, Cingolani M, Ferrante $\mathrm{L}$, Cameriere R. Age estimation in children by measurement of open apices in teeth: an Indian formula. Int $J$ Legal Med. 2010;124(3):237-241. $\underline{10.1007 / \mathrm{s} 00414-010-0427-7}$

13. Tompe A, Sargar K. X-Ray Image Quality Assurance. In: StatPearls [Internet]. Treasure Island (FL): StatPearls Publishing; 2021.

14. Sarkar S, Kailasam S, Mahesh Kumar P. Accuracy of estimation of dental age in comparison with chronological age in Indian population--a comparative analysis of two formulas. $J$ Forensic Leg Med. 2013;20(4):230-233. https://doi.org/10.1016/j.jflm.2012.09. $\underline{007}$

15. Galić I, Vodanović M, Cameriere R, Nakaš E, Galić E, Selimović E, et al. Accuracy of Cameriere, Haavikko, and Willems radiographic methods on age estimation on Bosnian-Herzegovian 
children age groups 6-13. Int J Legal

Med.2011;125(2):315-321.

https://doi.org/10.1007/s00414-010-

$\underline{0515-8}$

16. Soliman A, De Sanctis V, Elalaily R, Bedair $\mathrm{S}$. Advances in pubertal growth and factors influencing it: Can we increase pubertal growth? Indian J Endocrinol Metab. 2014;18(1):53-62. https://doi.org/10.4103/22308210.145075

17. Tabakcilar D, Bundak R, Gencay K. Dental Age in Precocious and Delayed Puberty Periods. Eur J Dent.2021; 15(3):539-545.

https://doi.org/10.1055/s-0041$\underline{1726156}$ 